\title{
Freshwater fluxes in the East Greenland Current: A decade of observations
}

\author{
L. de Steur, ${ }^{1}$ E. Hansen, ${ }^{1}$ R. Gerdes,${ }^{2}$ M. Karcher, ${ }^{3}$ E. Fahrbach, ${ }^{2}$ and J. Holfort ${ }^{1,4}$ \\ Received 7 October 2009; revised 3 November 2009; accepted 10 November 2009; published 15 December 2009.
}

[1] Over a decade of mooring measurements in the western Fram Strait at $78^{\circ} 50^{\prime} \mathrm{N}$ shows that the annual mean liquid freshwater flux (FWF) in the East Greenland Current is relatively constant at $-1274 \pm 453 \mathrm{~km}^{3} \mathrm{yr}^{-1}$ $(-40.4 \pm 14.4 \mathrm{mSv})$ despite the fact that the annual mean total volume transport of the EGC has more than doubled since 2001. This is shown to be due to an increase of the transport in the deeper ocean and the fact that the largest FW content is present on the East Greenland shelf and not in the core of the EGC. In order to capture the FWF on the shelf modeling results of NAOSIM are included showing that a mean contribution of FWF on the shelf of at least $-807 \pm 357 \mathrm{~km}^{3} \mathrm{yr}^{-1}(-25.6 \pm 11.3 \mathrm{mSv})$ should be added to the FWF obtained for the EGC. When compared to the extra input of freshwater required to account for the 19601990 freshening of the northern North Atlantic, the observed variations in the 1998-2008 EGC liquid freshwater fluxes are small. Citation: de Steur, L., E. Hansen, R. Gerdes, M. Karcher, E. Fahrbach, and J. Holfort (2009), Freshwater fluxes in the East Greenland Current: A decade of observations, Geophys. Res. Lett., 36, L23611, doi:10.1029/ 2009GL041278.

\section{Introduction}

[2] The northern North Atlantic features sites where weak stratification promotes formation of cold, dense waters, a key part of the meridional overturning circulation (MOC). Excessive amounts of freshwater could alter the stratification and density contrasts governing this northern limb of the MOC [Manabe and Stouffer, 1994]. The Arctic Ocean freshwater export through Fram Strait is a key parameter of the Arctic Ocean freshwater budget and a major link between the Arctic Ocean and the global climate system.

[3] A significant freshening in the subpolar North Atlantic from 1960 to 1990 [Curry and Mauritzen, 2005] was followed by a reversal of this trend in the upper ocean since the 1990s [Holliday et al., 2008]. Parts of this freshening has been attributed to pulses of excess freshwater released from the Arctic Ocean through Fram Strait, either as sea ice or as liquid freshwater [Dickson et al., 1988; Karcher et al., 2005].

\footnotetext{
${ }^{1}$ Norwegian Polar Institute, Polar Environmental Centre, Troms $\emptyset$, Norway.

${ }^{2}$ Alfred Wegener Institute for Polar and Marine Research, Bremerhaven, Germany.

${ }^{3}$ Ocean Atmosphere Systems, Hamburg, Germany.

${ }^{4}$ Now at Bundesamt für Seeschifffahrt und Hydrographie, Rostock, Germany.
}

Copyright 2009 by the American Geophysical Union. 0094-8276/09/2009GL041278\$05.00
[4] This paper presents time series of Fram Strait liquid freshwater fluxes observed directly by moorings over the period 1998-2008. The time series allows us to quantify Arctic freshwater fluxes carried by the East Greenland Current through Fram Strait in an era of widespread and seemingly accelerating Arctic change, such as record high rates of sea ice loss [Comiso et al., 2008] and increased river runoff [Peterson et al., 2006].

\section{Freshwater Calculation}

[5] Since 1997 up to present a mooring array has been maintained in the Fram Strait at $78^{\circ} 50^{\prime} \mathrm{N}$ (Figure 1), as a joint effort of the Norwegian Polar Institute (NPI) and the Alfred Wegener Institute for Polar and Marine Research (AWI). Six of the moorings cover the southward flowing East Greenland Current (EGC). Here, we calculate volume transport, freshwater content and freshwater flux in the EGC using salinities (S) and velocities (V) from mooring instruments. Errors in the obtained $\mathrm{S}$ and $\mathrm{V}$ fields due to vertical interpolation, and hence loss of realistic stratification, are reduced by incorporating Conductivity-Temperature-Depth (CTD) observations. Details on the data treatment can be found in the auxiliary material. ${ }^{5}$

[6] The freshwater content (FWC) is calculated as:

$$
F W C=\int_{z_{S=34.9}}^{z=0} \frac{S_{r e f}-S(z)}{S_{r e f}} d z
$$

It is the integral thickness of freshwater that accounts for the observed salinities that are lower than a reference salinity $\mathrm{S}_{\text {ref. }}$ We use a reference salinity $\mathrm{S}_{\text {ref }}=34.9$, the mean salinity in the Nordic Seas [Holfort et al., 2008]. The net southward freshwater flux (FWF) integrated over the section is then calculated as:

$$
F W F=\int_{x_{0 W}}^{x_{6.5 W}} \int_{z_{S=34.9}}^{z=0} V(x, z) \cdot \frac{S_{r e f}-S(x, z)}{S_{r e f}} d z d x
$$

\section{Results}

\subsection{Volume Transport, Freshwater Fluxes, and Content}

[7] The winter-centered annual mean values (calculated from July to June) of the southward volume transport in the EGC integrated over the mooring array from $6^{\circ} 30^{\prime} \mathrm{W}$ to $0^{\circ}$ are shown in Figure $2 \mathrm{a}$. The annual mean volume

\footnotetext{
${ }^{5}$ Auxiliary materials are available in the HTML. doi:10.1029/ 2009GL041278.
} 
a)

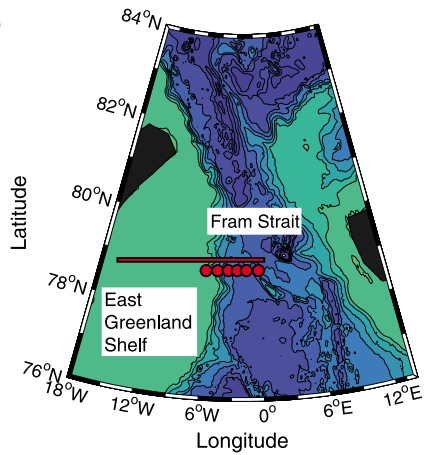

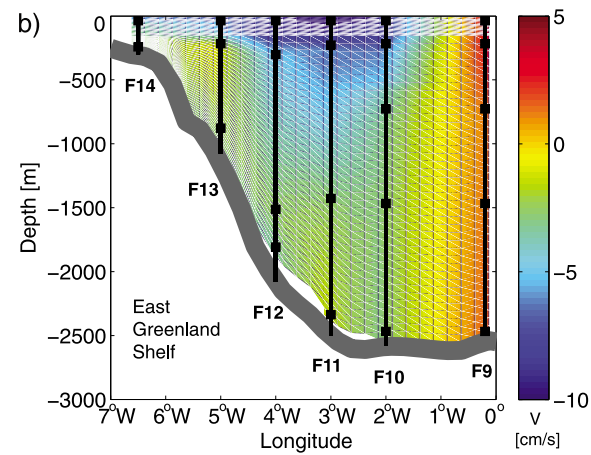

Figure 1. The mooring array in the EGC in Fram Strait. (a) The local bathymetry and the mooring locations shown as red dots. The red bar indicates the longitudes covered by the CTD and model section discussed in section 3.2, at the same latitude as the mooring section. (b) Vertical set up of the moorings. Color contours illustrate the mean velocity field where negative numbers denote southward direction.

transport shows a decrease in the first 4 years to a minimum of $-3.7 \pm 1.4 \mathrm{~Sv}$ in 2002 and an almost steady increase to a maximum of $-10 \pm 3.8 \mathrm{~Sv}$ in 2007. Earlier estimates of the EGC transport vary from $-4.1 \mathrm{~Sv}$ [Rudels, 1987] to $-11.1 \pm 1.7 \mathrm{~Sv}$ [Fahrbach et al., 2001]. We have separated the total volume transport into transport above and below 700 dbar depth, which divides the EGC in the strong upper core where mean velocities are larger than $5 \mathrm{~cm} \mathrm{~s}^{-1}$, and the portion below where velocities are $\sim 1-3 \mathrm{~cm} \mathrm{~s}^{-1}$ (Figure 1b). The change in total annual mean volume transport (Figure 2a) over the last 5 years is determined by changes in the transport in the deep ocean below $700 \mathrm{dbar}$ even though the upper ocean transport has also increased slightly. The annual mean FWF in the early 2000s shows strong interannual variations, which is not apparent in the total volume transport. In the second half of the observational period, the annual mean FWF coincides with the slight increase in transport above 700 dbar. The long-term mean FWF from these observations in the EGC is $-1274 \pm$ $453 \mathrm{~km}^{3} \mathrm{yr}^{-1}(-40.4 \pm 14.4 \mathrm{mSv})$. This is close to the early estimate of the liquid FWF into the Nordic Seas of $-1160 \mathrm{~km}^{3} \mathrm{yr}^{-1}(-37 \mathrm{mSv})$ relative to $\mathrm{S}_{\mathrm{ref}}=34.93$ by Aagaard and Carmack [1989], determined from hydrography only.
[8] Figure $2 \mathrm{~b}$ shows the mean seasonal cycle of the total volume transport, the FWF and integrated FWC. The volume transport shows a clear seasonal signal with a minimum in summer and a maximum in winter. The seasonal cycle of the FWF correlates well with the seasonal cycle of the volume transport $(\mathrm{r}=0.79)$ and slightly less with the seasonal cycle of total integrated FWF $(r=0.64)$. The mean seasonal cycle of the FWF shows a maximum in the fall when both the volume transport and the FWC are large.

[9] Contrary to expectations, the total integrated FWC across the EGC does not have a very prominent maximum in late summer when sea-ice melt is largest (Figure 2b) but there is large interannual variability as the standard deviation is largest in September. A Hovmöller diagram of monthly mean FWC along the Fram Strait mooring array (Figure 3a) shows maxima up to $12 \mathrm{~m}$ located on the shelf edge between $5^{\circ} \mathrm{W}$ and $6^{\circ} \mathrm{W}$. The maxima are not located in the core of the EGC which is around $3^{\circ} \mathrm{W}$ (Figure 1b). There, the FWC is close to $4 \mathrm{~m}$, decreasing fast to less than $1 \mathrm{~m}$ further east of the core. Strong freshening events in 2000 and 2002 reach across the EGC as far east as $0^{\circ}$ and late 2007 a large FWC is found on the shelf slope. a)

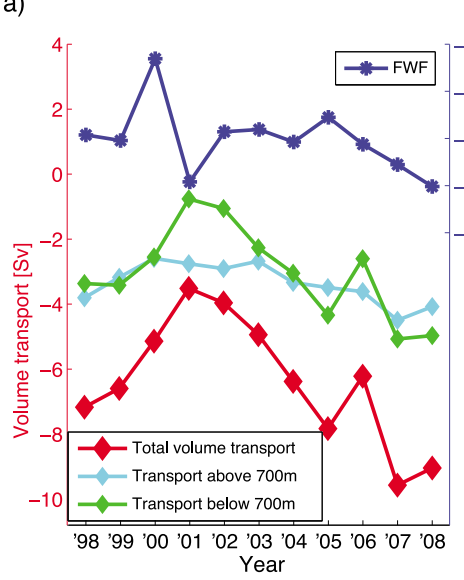

b)

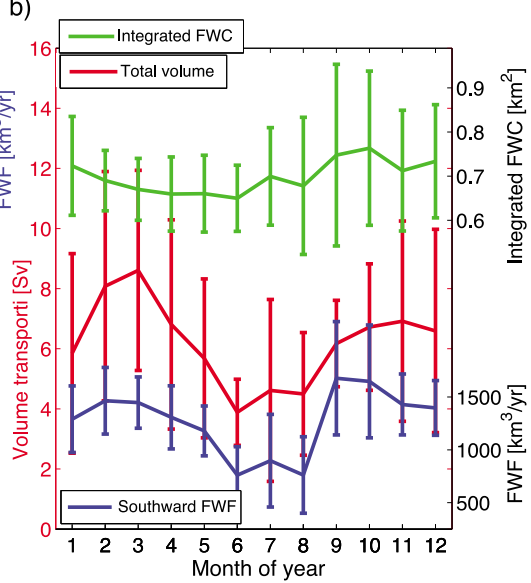

Figure 2. (a) Annual mean volume transports in the EGC: total transport, transport above 700 dbar, transport below 700 dbar, and the FWF. (b) Mean seasonal cycles of total volume transport, FWF, and the integrated FWC with \pm 1 standard deviation. 
a)

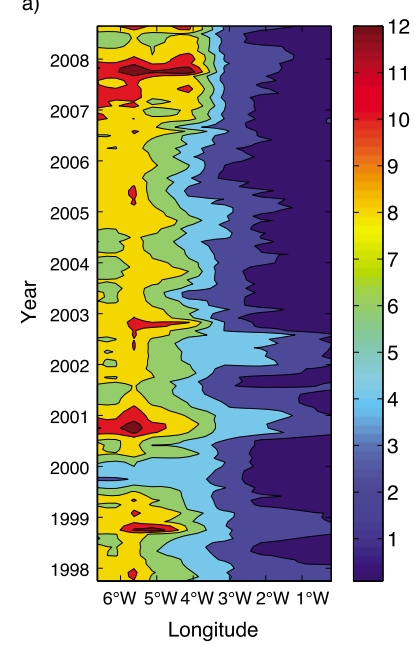

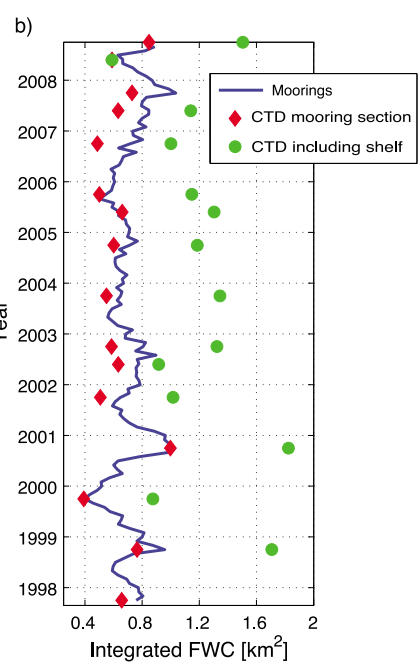

Figure 3. (a) FWC [m] as Hovmöller diagram (time versus longitude). (b) Integrated FWC $\left[\mathrm{km}^{2}\right]$ across the section from $6^{\circ} 30^{\prime} \mathrm{W}$ to $0^{\circ}$ from the moorings only (blue line), on the same section from CTD data only (red diamonds), and from CTD data covering the shelf farther west (green dots).

[10] The time series of FWC integrated over the mooring section (Figure 3b, blue line) emphasizes the minimum in fall 1999 followed by a peak in late 2000 and a small peak again in late 2007. For comparison, the integrated FWC from CTD data across the same section in the EGC are shown (red diamonds) as well as the integrated FWC from data including the shelf west of the EGC (green dots). In the first case FWC matches FWC from the moorings very well, indicating that our algorithm provides realistic FWC despite large spacing and lack of surface salinities. The FWC that includes the shelf, however, illustrates that moorings in the EGC capture the FWC only partially. If there is a substantial southward flow on the shelf, then the fluxes determined from the mooring array most likely underestimate the total FWF on this section.

\subsection{Freshwater Fluxes on the East Greenland Shelf}

[11] We investigate the uncertainty of the total FWF associated with the contribution of the shelf by using salinities and geostrophic velocities from CTD stations west of $6.5^{\circ} \mathrm{W}$. However, FWF estimates on the shelf depend sensitively on the zonal extent they are calculated for due to the presence of an anticyclonic shelf circulation [Budéus and Schneider, 1995]. Also, a large uncertainty stems from the lack of information of the barotropic flow. Hence, we compare observed estimates with that from a model experiment of NAOSIM (North Atlantic/Arctic Ocean Sea Ice Model; [Gerdes et al., 2008]) with $28 \mathrm{~km}$ resolution and 33 levels. Figures $4 \mathrm{a}$ and $4 \mathrm{~b}$ show salinity cross sections from CTD data and from the model in September 2003 covering the shelf. The model mimics the stratification on the shelf very well. The long-term mean modeled FWF in the EGC (between $6.5^{\circ} \mathrm{W}$ and $0^{\circ}$ ) is $-1445 \mathrm{~km}^{3} \mathrm{yr}^{-1}$, close to the observed estimate.

[12] September estimates of FWF on the shelf from hydrography and monthly and winter-centered annual mean time series calculated by the model are shown in Figure 4c.

In years with CTD coverage to at least $14^{\circ} \mathrm{W}$ ('98, '00,'02 and '03) the FWF on the shelf varies from $+80 \mathrm{~km}^{3} \mathrm{yr}^{-1}$ to $-342 \mathrm{~km}^{3} \mathrm{yr}^{-1}$. When the shelf is not fully sampled, the FWF on the shelf can be up to $-1975 \mathrm{~km}^{3} \mathrm{yr}^{-1}$. The model shows a large seasonal cycle with a small southward flux in early summer and a maximum in late fall. The modeled annual mean FWF over the shelf varies interannually between -232 and $-1477 \mathrm{~km}^{3} \mathrm{yr}^{-1}$ and the long-term mean is $-807 \mathrm{~km}^{3} \mathrm{yr}^{-1}$. The large southward FWF in 2006 is related to a large volume transport over the shelf and not due to freshening. The relative contribution of modeled

a)

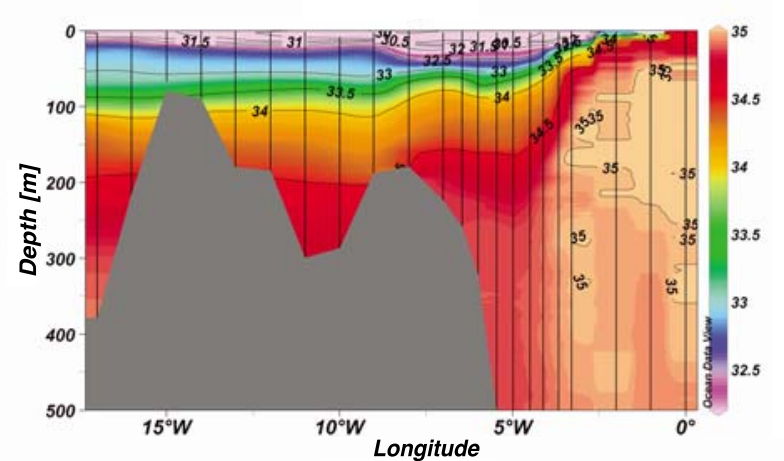

b)

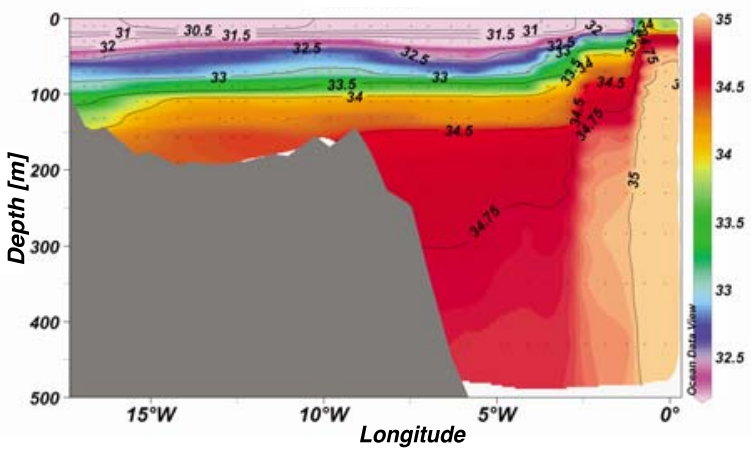

c)

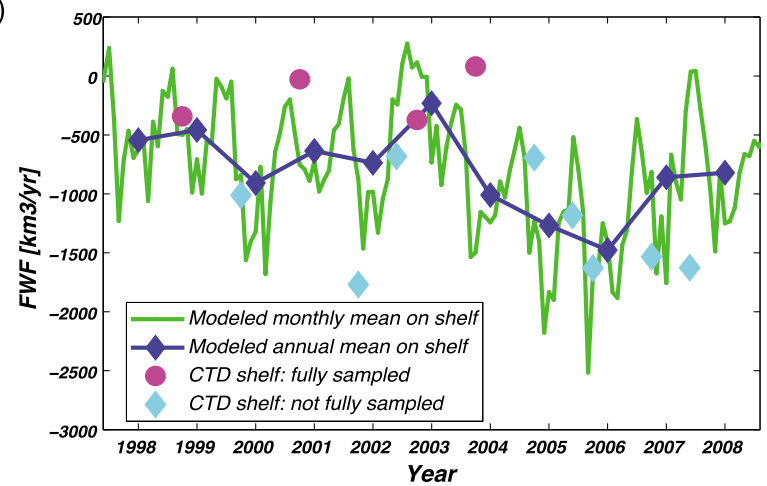

Figure 4. Cross section of salinity in September 2003 across the shelf from (a) CTD and (b) NAOSIM. The location of the cross section is indicated by the red bar in Figure 1a. In Figure $4 \mathrm{a}$ the depth mimics the maximum depths of the CTD casts, which are indicated as the vertical black lines, while in Figure $4 \mathrm{~b}$ the model topography is based on a blend of IBCAO and Etopo5 data sets. (c) Monthly and annual mean modeled FWF on the shelf and FWF obtained from CTD data. 
Table 1. Observed Mean FWF for Different Reference Salinities $\mathrm{S}_{\mathrm{ref}}$

\begin{tabular}{ccc}
\hline $\mathrm{S}_{\mathrm{ref}}$ & $\begin{array}{c}\text { EGC (Moorings) } \\
\mathrm{km}^{3} \mathrm{yr}^{-1}(\mathrm{mSv})\end{array}$ & $\begin{array}{c}\text { Shelf (Hydrography) } \\
\mathrm{km}^{3} \mathrm{yr}^{-1}(\mathrm{mSv})\end{array}$ \\
\hline 34.8 & $-1060 \pm 394(-33.6 \pm 12.5)$ & $-904 \pm 652(-28.7 \pm 20.7)$ \\
34.9 & $-1274 \pm 453(-40.4 \pm 14.4)$ & $-943 \pm 682(-29.9 \pm 21.6)$ \\
35.2 & $-2913 \pm 1056(-92.4 \pm 33.5)$ & $-1057 \pm 772(-33.5 \pm 24.5)$ \\
\hline
\end{tabular}

FWF on the shelf to the total southward FWF ranges from approximately $15 \%$ to $55 \%$.

[13] Rabe et al. [2009] found a FWF of $-1260 \mathrm{~km}^{3} \mathrm{yr}^{-1}$ on the shelf up to $10.6^{\circ} \mathrm{W}$ in September when seasonal FWF is largest. The model shows that annual mean FWF is roughly $83 \%$ of September FWF, which would correspond with $-1045 \mathrm{~km}^{3} \mathrm{yr}^{-1}$. Here, we take the long-term mean modeled FWF as an estimate on the shelf and we arrive at a total FWF of $-1274-807=-2081 \mathrm{~km}^{3} \mathrm{yr}^{-1}(-66 \mathrm{mSv})$ for the EGC and shelf combined. Table 1 sums up our estimates for different values of $\mathrm{S}_{\text {ref }}$.

\section{Discussion}

[14] Despite the fact that the Arctic Ocean has undergone vast changes, such as a large decrease in perennial sea-ice cover [Comiso et al., 2008], the freshening of the marginal seas in the Arctic observed in 2007 [Polyakov et al., 2008], and increased river runoff [Shiklomanov and Shiklomanov, 2003], the liquid FWF through Fram Strait does not show a pronounced trend over the observed decade although a small increase is observed in the last 3 years. How does an average annual liquid freshwater discharge of $-2081 \mathrm{~km}^{3}$ $\mathrm{yr}^{-1}$ compare to the other components in the freshwater budget in the subpolar seas? Dickson et al. [2007] provides a range of flux numbers from literature, which compare well with our estimates presented here. Here, however, we would like to put our flux estimates into perspective relative to the recent large loss of sea-ice volume and the 1960-1990 Northern North Atlantic freshening.

[15] Over the 1996-2007 period the Arctic sea ice cover shrank in area with about $111000 \mathrm{~km}^{2} \mathrm{yr}^{-1}$ [Comiso et al., 2008]. Ice thicknesses also declined [Giles et al., 2008], but here the representative numbers are more uncertain. If we assume that the average thickness of the ice that was lost ranges from 1 to $3 \mathrm{~m}$ with a mean salinity of 5 (seasonal and perennial), the sea-ice loss amounts to $95-285 \mathrm{~km}^{3} \mathrm{yr}^{-1}$ of freshwater. The fraction not directly lost by export as sea ice, enters the liquid freshwater budget. This remaining fraction may partially be reused for forming new ice or stored, or may be exported through one of the other Arctic gateways. Any remaining portion that is exported through Fram Strait is likely of such a magnitude that it is difficult to detect at the mooring array, taking into account the uncertainties inherent to the calculations. This, in short, means that we do not expect to observe the effects of the recent loss of sea-ice volume appearing in the liquid part of the Fram Strait freshwater directly.

[16] Based on sea-ice thicknesses observed at the same mooring array over the period 1991-1998, Kwok et al. [2004] estimated the annual volume flux of sea-ice in the Fram Strait to be $-2218 \mathrm{~km}^{3} \mathrm{yr}^{-1}$. Hence, the total annual mean freshwater flux, adding our own estimates from observations, is $-4299 \mathrm{~km}^{3} \mathrm{yr}^{-1}$. The 1965-1995 freshening of the Northern North Atlantic was a result of an additional $19000 \mathrm{~km}^{3}$ freshwater input over this period of which only $4000 \mathrm{~km}^{3}$ remained in the Nordic Seas [Curry and Mauritzen, 2005]. About half of this additional input occurred over about five years starting in the late 1960s, at a rate of about $2000 \mathrm{~km}^{3} \mathrm{yr}^{-1}$ [Dickson et al., 1988] which is $55 \%$ of the total annual Fram Strait export. This anomalous freshwater input is of the same order of magnitude as the annual mean Fram Strait export.

[17] A recent study indicates that the upper ocean in the Arctic Canadian basin has become much fresher relative to climatology, inducing an increase of steric height [McPhee et al., 2009]. On decadal time scales FWC changes in the Beaufort gyre are dominated by atmospheric circulation changes [Proshutinsky et al., 2009] which may lead to increased freshwater transports towards the Fram Strait or through the Canadian Archipelago in future. The long-term mooring array in Fram Strait enables us after 10 years for the first time to identify slow shifts in the liquid fresh water export from the Arctic. Still, these shifts are superimposed by strong interannual variability and the relationship between volume transport and fresh water transport remains an open research question. We need to maintain observational capability at this key site of the global ocean circulation to monitor future changes in the Arctic freshwater balance and its potential impact on the deep water formation in the subpolar North Atlantic.

[18] Acknowledgments. This work has been funded by the Norwegian Research Council and EU (VEINS, ASOF-N, and Damocles projects). The Damocles project is financed by the European Union in the 6th Framework program for Research and Development.

\section{References}

Aagaard, K., and E. C. Carmack (1989), The role of sea ice and other fresh water in the Arctic circulation, J. Geophys. Res., 94, 14,485-14,498.

Budéus, G., and W. Schneider (1995), On the hydrography of the Northeast Water Polynya, J. Geophys. Res., 100, 4287-4299.

Comiso, J., C. Parkinson, R. Gersten, and L. Stock (2008), Accelerated decline in the Arctic sea ice cover, Geophys. Res. Lett., 35, L01703, doi:10.1029/2007GL031972.

Curry, R., and C. Mauritzen (2005), Dilution of the northern North Atlantic Ocean in recent decades, Science, 308, 1772-1774.

Dickson, R. R., J. Meincke, S.-A. Malmberg, and A. J. Lee (1988), The "great salinity anomaly" in the northern North Atlantic, 1968-1982, Prog. Oceanogr., 20, 103-151.

Dickson, R., B. Rudels, S. Dye, M. Karcher, J. Meincke, and I. Yashayaev (2007), Current estimates of freshwater flux through Arctic and subarctic seas, Prog. Oceanogr., 73, 210-230, doi:10.1016/j.pocean.2006.12.003.

Fahrbach, E., J. Meincke, S. Østerhus, U. Schauer, V. Tverberg, and J. Verduin (2001), Direct measurements of volume transports through Fram Strait, Polar Res., 20, 217-224.

Gerdes, R., M. Karcher, C. Köberle, and K. Fieg (2008), Simulating the long term variability of liquid freshwater export from the Arctic Ocean, in Arctic-Subarctic Ocean Fluxes, edited by R. R. Dickson, J. Meincke, and P. Rhines, pp. 405-425, Springer, New York.

Giles, K. A., S. Laxon, and A. L. Ridout (2008), Circumpolar thinning of Arctic sea ice following the 2007 record ice extent minimum, Geophys. Res. Lett., 35, L22502, doi:10.1029/2008GL035710.

Holfort, J., E. Hansen, S. Østerhus, S. Dye, S. Jonsson, J. Meincke, J. Mortensen, and M. Meredith (2008), Freshwater fluxes east of Greenland, in Arctic-Subarctic Ocean Fluxes, edited by R. R. Dickson, J. Meincke, and P. Rhines, pp. 263-288, Springer, New York.

Holliday, N. P., et al. (2008), Reversal of the 1960s to 1990s freshening trend in the northeast North Atlantic and Nordic Seas, Geophys. Res. Lett., 35, L03614, doi:10.1029/2007GL032675.

Karcher, M., R. Gerdes, F. Kauker, C. Köberle, and I. Yashayaev (2005), Arctic Ocean change heralds North Atlantic freshening, Geophys. Res. Lett., 32, L21606, doi:10.1029/2005GL023861. 
Kwok, R., G. F. Cunningham, and S. S. Pang (2004), Fram Strait sea ice outflow, J. Geophys. Res., 109, C01009, doi:10.1029/2003JC001785.

Manabe, S., and R. J. Stouffer (1994), Multiple-century response of a coupled ocean-atmosphere model to an increase of atmospheric carbon dioxide, J. Clim., 7, 5-23.

McPhee, M. G., A. Proshutinsky, J. H. Morison, M. Steele, and M. B. Alkire (2009), Rapid change in freshwater content in the Arctic Ocean, Geophys. Res. Lett., 36, L10602, doi:10.1029/2009GL037525.

Peterson, B. J., J. McClelland, R. Curry, R. M. Holmes, J. E. Walsh, and K. Aagaard (2006), Trajectory shifts in the Arctic and Subarctic freshwater cycle, Science, 313, 1061-1066, doi:10.1126/science.1122593.

Polyakov, I. V., V. A. Alexeev, V. V. Ivanov, G. I. Belchansky, S. A. Kirillov, A. A. Korablev, L. A. Timokhov, M. Steele, and I. Yashayaev (2008), Arctic Ocean freshwater changes over the past 100 years and their causes, J. Clim., 21, 364-384.

Proshutinsky, A., R. Krishfield, M.-L. Timmermans, J. Toole, E. Carmack, F. McLaughlin, W. J. Williams, S. Zimmerman, M. Itoh, and K. Shimada (2009), The Beaufort Gyre freshwater reservoir: State and variability from observations, J. Geophys. Res., 114, C00A10, doi:10.1029/ 2008JC005104.
Rabe, B., U. Schauer, A. Mackensen, M. Karcher, E. Hansen, and A. Beszcynska-Möller (2009), Freshwater components and transports in the Fram Strait: Recent observations and changes since the late 1990s, Ocean Sci., 5, 219-233.

Rudels, B. (1987), On the mass balance of the Polar Ocean, with special emphasis on the Fram Strait, Norsk Polarinst. Skr., 188, 1-53.

Shiklomanov, I. A., and A. I. Shiklomanov (2003), Climate changes and the dynamics of river runoff into the Arctic Ocean, Water Res., 30, 593-601.

L. de Steur and E. Hansen, Norwegian Polar Institute, Polar Environmental Centre, N-9296 Troms $\varnothing$, Norway. (desteur@npolar.no)

E. Fahrbach and R. Gerdes, Alfred Wegener Institute for Polar and Marine Research, Bussestr. 24, D-27570 Bremerhaven, Germany.

J. Holfort, Bundesamt für Seeschifffahrt und Hydrographie, Neptunallee 5, D-18057 Rostock, Germany

M. Karcher, Ocean Atmosphere Systems, Schanzenstr. 36, D-20357 Hamburg, Germany. 